\title{
Surgeons' beliefs and perceptions about removal of orthopaedic implants
}

\author{
Beate Hanson ${ }^{1}$, Chris van der Werken ${ }^{1,2}$ and Dirk Stengel ${ }^{* 1,3}$
}

\begin{abstract}
Address: ${ }^{1} \mathrm{AO}$ Foundation, Clinical Investigation and Documentation, Dübendorf, Switzerland, ${ }^{2}$ Division of Surgical Specialties, University Medical Centre Utrecht, Utrecht, The Netherlands and ${ }^{3}$ Center for Clinical Research, Depts of Orthopaedic and Trauma Surgery, Unfallkrankenhaus Berlin and University of Greifswald, Germany

Email: Beate Hanson - beate.hanson@aofoundation.org; Chris van der Werken - c.werken@planet.nl; Dirk Stengel* - dirk.stengel@ukb.de

* Corresponding author
\end{abstract}

Published: 24 May 2008

BMC Musculoskeletal Disorders 2008, 9:73 doi:10.1 186/147|-2474-9-73

This article is available from: http://www.biomedcentral.com/I47/-2474/9/73

(c) 2008 Hanson et al; licensee BioMed Central Ltd.

This is an Open Access article distributed under the terms of the Creative Commons Attribution License (http://creativecommons.org/licenses/by/2.0), which permits unrestricted use, distribution, and reproduction in any medium, provided the original work is properly cited.
Received: 27 December 2007

Accepted: 24 May 2008

\begin{abstract}
Background: The routine removal of orthopaedic fixation devices after fracture healing remains an issue of debate. There are no evidence-based guidelines on this matter, and little is known on surgeons' practice and perceived effectiveness of implant removal in different clinical settings.

Methods: A 4I-item questionnaire was distributed to 730 attendees of the AO Principles and Masters Courses of Operative Fracture Treatment in Davos, Switzerland, to assess their attitudes towards removal of different types of implants, and perceived benefits and risks with this common procedure.

Results: The response rate was $655 / 730$ (89.7\%), representing $54.6 \%$ of all I I 99 course attendees. Surgeons from 65 countries ( 57 I males and 84 females, mean age $39 \pm$ SD 9 years) took part in the survey. Fifty-eight percent of the participants did not agree that routine implant removal is necessary, and $49 \%$ and $58 \%$ did not agree that indwelling implants pose an excess risk for fractures or general adverse effects. Forty-eight percent felt that removal is riskier than leaving the implant in situ. Implant removal in symptomatic patients was rated to be moderately effective (mean rating on a 10-point-scale, 5.8, 95\% confidence interval 5.7-6.0). Eighty-five percent of all participants agreed that implant removal poses a burden to hospital resources. Surgeons were undetermined whether implant removal is adequately reimbursed by payers of health care services (44\% "I-don'tknow"-answers).

Conclusion: Many surgeons refuse a routine implant removal policy, and do not believe in clinically significant adverse effects of retained metal implants. Given the frequency of the procedure in orthopaedic departments worldwide, there is an urgent need for a large randomized trial to determine the efficacy and effectiveness of implant removal with regard to patient-centred outcomes.
\end{abstract}

\section{Background}

Implant removal belongs to the most common elective orthopaedic procedures in the industrial countries. In a frequently cited Finnish study, implant removal contrib- uted to almost $30 \%$ of all planned orthopaedic operations, and $15 \%$ of all operations of the department [1].

Controversy exists as to the need for routine implant removal. In children, it may be necessary to remove 
implants early to avoid disturbances to the growing skeleton, to prevent their bony immuring making later removal technically difficult or impossible, and to allow for planned reconstructive surgery after skeletal maturation (e.g., in case of hip dysplasia).

In adults, pain, soft tissue irritation, the resumption of strenuous activities or contact sports after fracture healing, and the patient's demand are typical indications for implant removal in clinical practice. Many surgeons will remember patients whose intractable, hardly explainable local symptoms and complaints resolved quickly after the procedure. However, implant removal requires a second surgical procedure in scarred tissue, and poses a risk for nerve damage and re-fractures [2-5].

Pain may even worsen after implant removal. In a series of 109 femoral nail removals, an increase in pain and discomfort was noted in $4 / 58(7 \%)$ of all patients with, and $10 / 51(20 \%)$ of all patients without pre-operative symptoms [6]. Similar observations were made in subjects who had undergone open reduction and internal fixation of ankle fractures [7].

Corrosion, systemic release of nickel, chromium, and cobalt, and its presumed toxic, allergic, and even carcinogenic potential have been linked to stainless steel implants. As yet, none of these adverse effects had convincingly been confirmed in the clinical setting [8]. Orthopedic fixation devices made from titanium alloy are considered less susceptible to degradation and safe to be retained in situ $[9,10]$, but titanium and aluminum had been traced in serum and hair of 16 of 46 patients after spinal instrumentation as well [11].

Little is known on the attitudes of orthopedic surgeons towards implant removal $[12,13]$. We reasoned that a questionnaire survey may be an appropriate method to evaluate surgeons' perceptions about the need, effectiveness, and risks of this common procedure in different clinical settings.

\section{Methods}

We developed a three-page questionnaire with 41 items to determine surgeons' opinions and concerns about implant removal. As a first step, DS undertook a literature review in Pubmed Medline, Embase, SciSearch, and Google to identify available instruments assessing surgeons' beliefs and assumptions about implant removal and other common orthopedic procedures. We considered the items queried by Loder et al. in a recent web survey pragmatic and relevant for this study, and used them as a core set [12]. We then followed a sample-to-redundancy strategy to compile a comprehensive set of items describing the baseline profile of participants, potential
Table I: Demographic profile of the respondents.

\begin{tabular}{lc}
\hline Characteristic & \\
\hline Mean age, years (SD) & $38.8(9.3)$ \\
Median age, years (range) & $36(26-71)$ \\
Gender & \\
Male & $571(87.2 \%)$ \\
Female & $84(12.8 \%)$ \\
Professional background & \\
General surgeon & $96(14.7 \%)$ \\
Orthopedic surgeon & $361(55.2 \%)$ \\
Trainee & $121(18.5 \%)$ \\
Spine surgeon & $7(1.1 \%)$ \\
Other & $69(10.6 \%)$ \\
Affiliation & \\
University hospital & $277(42.3 \%)$ \\
Public, non-university hospital & $303(46.3 \%)$ \\
Private hospital & $61(9.3 \%)$ \\
Other & $14(2.1 \%)$ \\
Current position & \\
Chief of staff & $128(20.0 \%)$ \\
Consultant & $174(27.1 \%)$ \\
Intern/resident & $215(33.5 \%)$ \\
Other & $124(19.3 \%)$ \\
Origin & \\
Africa & $29(4.5 \%)$ \\
Asia & $58(9.0 \%)$ \\
Australia & $8(1.2 \%)$ \\
Europe & $370(72.9 \%)$ \\
North America & $38(5.9 \%)$ \\
South America & $42(6.5 \%)$ \\
\hline
\end{tabular}

confounders, and relevant endpoints [14-16]. The preliminary version of the questionnaire was emailed between the authors, who added, deleted, and revised individual items and questions until consensus was reached. The final version of the instrument was reviewed by three clinical experts (see acknowledgments), who felt comfortable with its overall extent, scope of questions, and scaling of possible answers.

The form contained three parts: 1) demographic information (including age, gender, level of training and specialization, current affiliation, and origin), 2) general beliefs about potential benefits and harms of retained material and removal surgery, and 3) reasons for removing implants (e.g., type of implant, clinical conditions demanding removal).

We requested participants to describe their practice of informing patients about the need for later implant removal at the time of fracture repair, and to estimate the influence of removal surgery on patients' complaints. Because cold welding may cause problems when attempting to remove interlocking plates, surgeons were asked how often they observe screw breakages, irremovable implant, and fractures with this frequently used material. 
General beliefs were polled by 5-point Likert-scales. Answer options included "I strongly agree," "I strongly disagree," "I don't know," "I disagree," and "I strongly disagree." For all other questions, ratings were made on 10point scales ranging from " $1=$ never" to " $10=$ always."

The survey was conducted during the last three days of the first, and the first three days of the second course week. A booth was established at the main entrance hall of the conference venue to allow participants for completing the questionnaire in a quiet and comfortable surrounding. Assistants addressed course attendants personally and invited them to participate in the survey. Also, posters were put up at main meeting places and the industrial exhibition explaining the goal of the study. As an incentive, all respondents took part in a drawing for an iPod $^{\circledast}$ player.

A consent waiver was granted by the Cantonal Ethics Board of Zurich. The participants were informed that, by filling out the questionnaire, they agreed in using the anonymously gathered data for research and publication.

All analyses were made in an exploratory intent, and we did not pose a formal null-hypothesis. The target sample size was planned to yield a certain precision of estimates, not to detect a relevant difference between groups with predefined type I and II errors [17]. A sample size of 650 eligible forms guaranteed standard errors $\leq 5 \%$ for proportions (in case of Likert-scale type answers) and continuous endpoints (i.e., 10-point scales). To compensate for a drop-out rate of $10 \%$, a total of 730 forms were distributed during the meeting.

According to the quality of data, results are presented as proportions, means, or medians with their adequate measures of distribution and 95\% confidence intervals (CI). For subgroup analyses (i.e., age, gender, profession, affiliation, origin), Likert-scale type ratings were analyzed by ordered logistic regression. Ten-point scales were analyzed by general linear models. To ease reading and data interpretation, the results from queries on general opinions about implant removal are expressed as proportions of disagreement (including "I strongly disagree" and "I disagree") and agreement (including "I strongly agree" and "I agree").

\section{Results}

Of 730 distributed questionnaires, 655 (89.7\%) were completed. This represented $54.6 \%$ of all 1199 attendees of the 2006 AO Principles and Masters Courses. Surgeons from 65 countries with a mean age of $38.8 \pm$ SD 9.3 years (range, 26 to 71 years) took part in the survey. There were 571 males and 84 women. The demographic profile is summarized in Table 1.

Table 2 summarizes the distribution of answers to questions about general opinions and attitudes. Many surgeons did not agree that orthopedic implants need to be routinely removed in younger, asymptomatic patients (disagreement: $57.8 \%$, agreement: $37.1 \%$ ). Also, many participants did not believe that indwelling implant pose

Table 2: Proportions of agreement and disagreement in statements about general attitudes towards implant removal.

\begin{tabular}{|c|c|c|c|c|c|c|}
\hline Statement & $\mathbf{n}$ & $\begin{array}{l}\text { I strongly } \\
\text { agree }\end{array}$ & I agree & I don't know & I disagree & $\begin{array}{l}\text { I strongly } \\
\text { disagree }\end{array}$ \\
\hline $\begin{array}{l}\text { Orthopedic implants must be removed in younger } \\
\text { patients ( }<40 \text { years of age), even if they cause no } \\
\text { problems }\end{array}$ & 645 & $\begin{array}{l}39(6.0 \%) \\
{[4.3-8.2 \%]}\end{array}$ & $\begin{array}{l}200(31.0 \%) \\
{[27.5-34.7 \%]}\end{array}$ & $\begin{array}{l}33(5.1 \%) \\
{[3.5-7.1 \%]}\end{array}$ & $\begin{array}{l}297(46.0 \%) \\
{[42.1-50.0 \%]}\end{array}$ & $\begin{array}{l}76(11.8 \%) \\
{[9.4-14.5 \%]}\end{array}$ \\
\hline Leaving implants in-situ poses a risk for later fractures & 645 & $\begin{array}{l}15(2.3 \%) \\
{[1.3-3.8 \%]}\end{array}$ & $\begin{array}{l}212(32.9 \%) \\
{[29.3-36.6 \%]}\end{array}$ & $\begin{array}{l}104(16.1 \%) \\
{[13.4-19.2 \%]}\end{array}$ & $\begin{array}{l}287(44.5 \%) \\
{[40.6-48.4 \%]}\end{array}$ & $\begin{array}{l}27(4.2 \%) \\
{[2.8-6.0 \%]}\end{array}$ \\
\hline $\begin{array}{l}\text { Titanium implants are safer to be kept in-situ than } \\
\text { devices made from stainless steel }\end{array}$ & 647 & $\begin{array}{l}48(7.4 \%) \\
{[5.5-9.7 \%]}\end{array}$ & $\begin{array}{l}252(38.9 \%) \\
{[35.2-42.8 \%]}\end{array}$ & $\begin{array}{l}180(27.8 \%) \\
{[24.4-31.4 \%]}\end{array}$ & $\begin{array}{l}148(22.9 \%) \\
{[19.7-26.3 \%]}\end{array}$ & $\begin{array}{l}19(2.9 \%) \\
{[1.8-4.5 \%]}\end{array}$ \\
\hline $\begin{array}{l}\text { In case of otherwise unexplained pain and functional } \\
\text { deficits, implant removal is a good option to improve } \\
\text { the physical status }\end{array}$ & 646 & $\begin{array}{c}51(7.9 \%) \\
{[5.9-10.2 \%]}\end{array}$ & $\begin{array}{c}394(61.0 \%) \\
{[57.1-64.8 \%]}\end{array}$ & $\begin{array}{l}78(12.1 \%) \\
{[9.7-14.8 \%]}\end{array}$ & $\begin{array}{l}111(17.2 \%) \\
{[14.4-20.3 \%]}\end{array}$ & $\begin{array}{l}12(1.9 \%) \\
{[1.0-3.2 \%]}\end{array}$ \\
\hline $\begin{array}{l}\text { Leaving implants in-situ increases the life-time risk for } \\
\text { chronic infections, allergy, and cancer }\end{array}$ & 649 & $\begin{array}{l}15(2.3 \%) \\
{[1.3-3.8 \%]}\end{array}$ & $\begin{array}{c}107(16.5 \%) \\
{[13.7-19.6 \%]}\end{array}$ & $\begin{array}{l}150(23.1 \%) \\
{[19.9-26.6 \%]}\end{array}$ & $\begin{array}{l}310(47.8 \%) \\
{[43.9-51.7 \%]}\end{array}$ & $\begin{array}{l}67(10.3 \%) \\
{[8.1-12.9 \%]}\end{array}$ \\
\hline $\begin{array}{l}\text { Removing implants is a surgical procedure which drains } \\
\text { valuable hospital resources }\end{array}$ & 644 & $\begin{array}{l}114(17.7 \%) \\
{[14.8-20.9 \%]}\end{array}$ & $\begin{array}{l}436(67.7 \%) \\
{[63.9-71.3 \%]}\end{array}$ & $\begin{array}{l}21(3.3 \%) \\
{[2.0-4.9 \%]}\end{array}$ & $\begin{array}{l}71(11.0 \%) \\
{[8.7-13.7 \%]}\end{array}$ & $\begin{array}{c}2(0.3 \%)[0.0- \\
1.1 \%]\end{array}$ \\
\hline $\begin{array}{l}\text { Removing implants damages healed soft tissue, and is } \\
\text { riskier than retaining the device }\end{array}$ & 643 & $\begin{array}{l}29(4.5 \%) \\
{[3.0-6.4 \%]}\end{array}$ & $\begin{array}{l}281(43.7 \%) \\
{[39.8-47.6 \%]}\end{array}$ & $\begin{array}{l}75(11.7 \%) \\
{[9.3-14.4 \%]}\end{array}$ & $\begin{array}{l}243(37.8 \%) \\
{[34.0-41.7 \%]}\end{array}$ & $\begin{array}{c}15(2.3 \%) \\
{[1.3-3.8 \%]}\end{array}$ \\
\hline $\begin{array}{l}\text { Given the time and efforts required for implant } \\
\text { removal, this procedure is not adequately reimbursed } \\
\text { by insurance companies }\end{array}$ & 642 & $\begin{array}{c}46(7.2 \%) \\
{[5.3-9.4 \%]}\end{array}$ & $\begin{array}{c}190(29.6 \%) \\
{[26.1-33.3 \%]}\end{array}$ & $\begin{array}{c}285(44.4 \%) \\
{[40.5-48.3 \%]}\end{array}$ & $\begin{array}{l}112(17.4 \%) \\
{[14.6-20.6 \%]}\end{array}$ & $\begin{array}{c}9(1.4 \%)[0.6- \\
2.6 \%]\end{array}$ \\
\hline $\begin{array}{l}\text { Patients should take responsibility for the incurring } \\
\text { costs of implant removal }\end{array}$ & 642 & $\begin{array}{l}15(2.3 \%) \\
{[1.3-3.8 \%]}\end{array}$ & $\begin{array}{c}109(17.0 \%) \\
{[14.2-20.1 \%]}\end{array}$ & $\begin{array}{l}91(14.2 \%) \\
{[11.6-17.1 \%]}\end{array}$ & $\begin{array}{l}328(51.1 \%) \\
{[47.1-55.0 \%]}\end{array}$ & $\begin{array}{c}99(15.4 \%) \\
{[12.7-18.5 \%]}\end{array}$ \\
\hline
\end{tabular}

$\mathrm{n}=$ number of available answers. Percentages in brackets are $95 \%$ confidence intervals. 


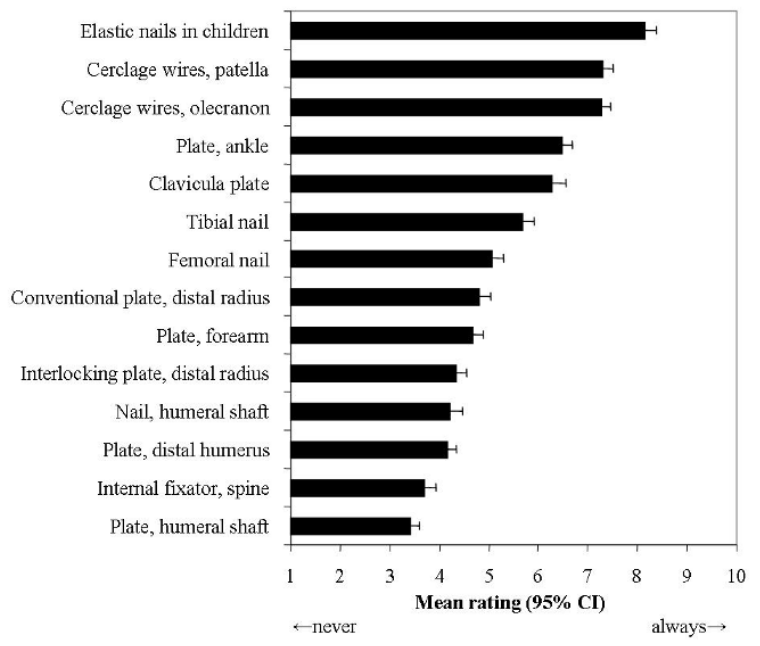

Figure I

Assigned removal priority to different types of implants. Mean ratings on 10 -point scales with $95 \%$ confidence intervals.

an excess risk for fractures (disagreement: $48.7 \%$, agreement: $35.2 \%$ ) and allergy or malignancy (disagreement: 58.1\%, agreement: 18.8\%). Titanium was considered safer to be retained than stainless steel material (disagreement: $25.8 \%$, agreement: $46.4 \%$ ).

In contrast to the overall tendency against routine metal removal, $68.9 \%$ of all respondents agreed that it represents a therapeutic option in case of otherwise unexplained pain and functional deficits (disagreement: $19.0 \%)$. Interestingly, implant removal was considered only moderately effective in resolving local symptoms (mean rating 5.8, 95\% CI 5.7 - 6.0).

Orthopedic surgeons were less enthusiastic about the appropriateness of implant removal in case of "symptomatic" implant than general surgeons. Both had similar opinions about the moderate effectiveness of this procedure.

A similar proportion of participants disagreed and agreed that implant removal causes additional soft tissue damage (40.1\% versus $48.2 \%$ ).

Most respondents considered implant removal a procedure that drains valuable hospital resources (agreement: $85.4 \%$, disagreement: $11.3 \%$ ).

Nearly half of all surgeons (44.4\%) could not decide whether implant removal is adequately reimbursed by health care insurance carriers, and $36.8 \%$ and $18.8 \%$ agreed and disagreed that payments are inadequate for the

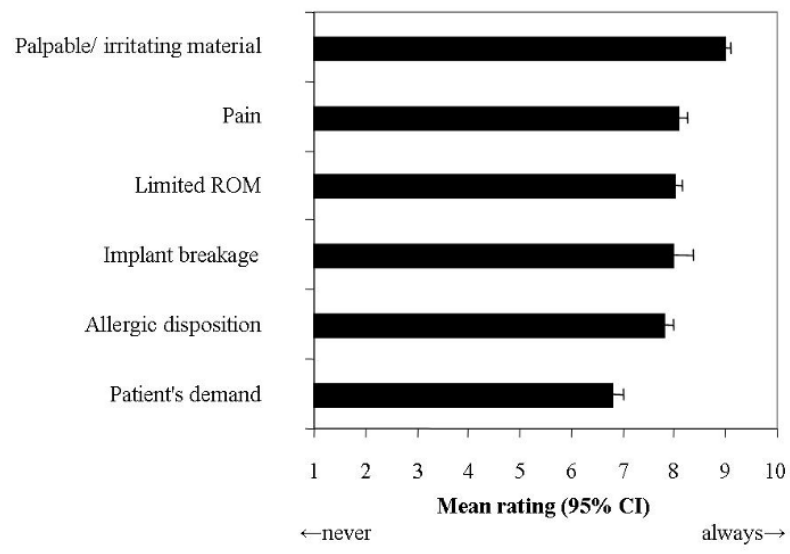

Figure 2

Main indications for implant removal. Mean ratings on 10 -point scales with $95 \%$ confidence intervals.

procedure. However, most surgeons won't charge patients to pay for implant removal by themselves (disagreement: 66.5\%, agreement: $19.3 \%$ ).

With a mean rating of 8.2 (95\% CI 7.9 - 8.4) on a 10 point-scale, surgeons would recommend the regular removal of elastic titanium nails in children, followed by almost identical ratings for cerclage wires after fixation of fractures of the patella and the elbow (mean rating 7.3, 95\% CI 7.1 - 7.5, mean difference 1.5 point, 95\% CI 1.3 -1.7 points, $\mathrm{p}<0.0001)$. Plates at the humeral shaft were assigned the lowest priority for removal (mean rating 3.4, $95 \%$ CI $3.2-3.6)$. Findings are illustrated in Figure 1.

Palpable and irritating material was considered the main indication for metal removal (mean rating 8.9, 95\% CI $8.8-9.1$ ), whereas the patient's demand ranked lowest on the list of potential indications (mean rating 6.8, 95\% CI $6.6-7.0)$. Results are depicted in Figure 2.

Surgeons tended towards informing patients about the need for later implant removal at the time of fracture repair (mean rating $7.6,95 \%$ CI $7.4-7.8$ ).

Participants reported low rates of intra- and post-operative screw breakages $(4.0,95 \%$ CI $3.8-4.2)$, irremovable implants $(3.0,95 \%$ CI $2.9-3.2)$, and re-fractures $(2.5$, $95 \%$ CI $2.3-2.6)$.

Table 3 summarizes the findings from ordered logistic regression analysis. Older respondents, Europeans, and university-affiliated surgeons were more likely to agree that implants must be removed in younger patients. Titanium was considered safer to be retained than stainless steel by older participants, non-orthopedic surgeons, and 
Table 3: Variables contributing to the likelihood of agreement in the different statements about general attitudes towards implant removal.

\begin{tabular}{|c|c|c|c|c|c|c|}
\hline Statement & Surgeons' age & $\begin{array}{c}\text { Male versus } \\
\text { female surgeon }\end{array}$ & $\begin{array}{l}\text { Orthopedic ver- } \\
\text { sus non-ortho- } \\
\text { pedic surgeon }\end{array}$ & $\begin{array}{l}\text { European ver- } \\
\text { sus US-Ameri- } \\
\text { can origin }\end{array}$ & $\begin{array}{l}\text { European ver- } \\
\text { sus non-Euro- } \\
\text { pean origin }\end{array}$ & $\begin{array}{l}\text { University ver- } \\
\text { sus other affilia- } \\
\text { tion }\end{array}$ \\
\hline $\begin{array}{l}\text { Orthopedic implants } \\
\text { must be removed in } \\
\text { younger patients ( }<40 \\
\text { years of age), even if } \\
\text { they cause no } \\
\text { problems }\end{array}$ & $1.03(1.01-1.04)$ & $1.12(0.74-1.70)$ & $1.23(0.92-1.64)$ & $7.40(3.77-14.50)$ & $1.56(1.12-2.18)$ & $0.72(0.54-0.97)$ \\
\hline $\begin{array}{l}\text { Leaving implants in-situ } \\
\text { poses a risk for later } \\
\text { fractures }\end{array}$ & $0.99(0.98-1.01)$ & $1.32(0.86-2.02)$ & $1.13(0.84-1.50)$ & 2.81 (I.44-5.47) & $0.98(0.7 \mathrm{I}-1.35)$ & $0.79(0.59-1.06)$ \\
\hline $\begin{array}{l}\text { Titanium implants are } \\
\text { safer to be kept in-situ } \\
\text { than devices made } \\
\text { from stainless steel }\end{array}$ & $1.02(1.00-1.04)$ & $0.82(0.54-1.22)$ & $0.72(0.54-0.96)$ & $2.16(1.18-3.97)$ & $1.05(0.76-1.45)$ & $1.04(0.78-1.38)$ \\
\hline $\begin{array}{l}\text { In case of otherwise } \\
\text { unexplained pain and } \\
\text { functional deficits, } \\
\text { implant removal is a } \\
\text { good option to } \\
\text { improve the physical } \\
\text { status }\end{array}$ & $1.00(0.98-1.02)$ & $0.86(0.53-1.38)$ & $0.73(0.54-1.00)$ & $2.74(\mathrm{I} .47-5.1 \mathrm{I})$ & $1.81(1.28-2.55)$ & $0.83(0.61-1.13)$ \\
\hline $\begin{array}{l}\text { Leaving implants in-situ } \\
\text { increases the life-time } \\
\text { risk for chronic } \\
\text { infections, allergy, and } \\
\text { cancer }\end{array}$ & $1.01(0.99-1.03)$ & $1.14(0.74-1.76)$ & $1.26(0.94-1.68)$ & $1.66(0.90-3.08)$ & $0.99(0.72-1.37)$ & $0.92(0.69-1.22)$ \\
\hline $\begin{array}{l}\text { Removing implants is a } \\
\text { surgical procedure } \\
\text { which drains valuable } \\
\text { hospital resources }\end{array}$ & $1.00(0.98-1.02)$ & $1.5 \mathrm{I}(0.9 \mathrm{I}-2.48)$ & $0.99(0.72-1.38)$ & $1.39(0.68-2.84)$ & I.II (0.77-I.60) & I.08 (0.78-I.50) \\
\hline $\begin{array}{l}\text { Removing implants } \\
\text { damages healed soft } \\
\text { tissue, and is riskier } \\
\text { than retaining the } \\
\text { device }\end{array}$ & $0.99(0.97-1.00)$ & $1.06(0.69-1.64)$ & 0.91 (0.68-I.22) & $1.20(0.65-2.23)$ & $1.20(0.65-2.23)$ & $1.36(1.01-1.82)$ \\
\hline $\begin{array}{l}\text { Given the time and } \\
\text { efforts required for } \\
\text { implant removal, this } \\
\text { procedure is not } \\
\text { adequately reimbursed } \\
\text { by insurance } \\
\text { companies }\end{array}$ & $1.02(1.00-1.03)$ & $1.41(0.93-2.14)$ & $1.43(1.07-1.91)$ & $0.37(0.19-0.70)$ & $0.37(0.19-0.70)$ & $1.25(0.93-1.67)$ \\
\hline $\begin{array}{l}\text { Patients should take } \\
\text { responsibility for the } \\
\text { incurring costs of } \\
\text { implant removal }\end{array}$ & $1.03(1.01-1.05)$ & $2.39(1.52-3.76)$ & $1.61(1.20-2.16)$ & $0.48(0.26-0.91)$ & $0.24(0.17-0.34)$ & 1.31 (0.98-I.75) \\
\hline
\end{tabular}

Numbers are odds ratios derived from ordered logistic regression, with $95 \%$ confidence intervals in parentheses. Values $>1$ indicate a higher likelihood of agreement, and values $<1$ indicate a higher likelihood in disagreement. If the $95 \%$ confidence limits exclude I, statistically significant results can be assumed at the two-tailed $5 \%$ threshold.

Europeans. Also, non-orthopedic and European surgeons were more likely to agree that implant removal is a good therapeutic option to improve pain and function.

Older, male, non-European, and university-based surgeons were more likely to agree that implant removal is inadequately reimbursed by health-care insurers.

\section{Discussion}

In 1988, an estimated number of 4.9 million US American citizens had prevalent fixation devices [18]. With expanding indications for operative fracture treatment in all age groups and fracture types, it is likely that this number has substantially increased during the last two decades. 
The findings from this survey indicate that about $60 \%$ of all surgeons do not agree in a routine removal policy in asymptomatic subjects, and that the patient's request is the less important reason to remove material. Many surgeons doubt clinically significant adverse effects of indwelling metal like stress shielding or an allergic or even carcinogenic potential [19-22], and acknowledge the burden of implant removal to hospital resources.

While there are absolute (e.g., cartilage damage by intraarticular screws, skin and soft tissue irritation by prominent material) and relative indications to take out implant (e.g., to reduce artifacts with planned MRI and CT imaging), the discrepancy between physical findings, imaging results and complaints can be remarkable. Given the apparently quick and safe removal procedure, many surgeons may be tempted to take their patients to the operating theatre instead of conservative management or watchful waiting.

There is currently no controlled trial that would allow for a valid trade-off between the benefits and harms of implant removal, and scientifically grounded counseling of patients. In addition to the possibility of retained material and another period of sick leave and restricted weight bearing, patients must be informed about potential risks of the removal operation [6,8,23-25]. In a review of 14 studies enrolling 635 patients who underwent removal of forearm plates, the overall incidence of complications ranged from 12 to $40 \%$ [26]. Iatrogenic nerve injuries were noted in 2 to $29 \%$, refractures in 2 to $26 \%$, and wound infections in 5 to $12 \%$ of all studies.

According to eight retrospective studies enrolling 346 symptomatic patients (Table 4), the weighted success rate (i.e., a complete or marked reduction of pain) of implant removal can be estimated at $78 \%$. On the other hand, the weighted failure rate (including subjects with worsening pain) is $22 \%$, or about 1 in 5 patients. In a recent prospec- tive study of 60 patients, mean pain scale, Short Musculoskeletal Function Assessment (SMFA), and Short Form 36 Physical Component Scores (SF36-PCS) significantly improved over one year after removal of painful implants [25]. With 13 different anatomic sites, and a mean in-situ time ranging from six months to nine years, unspecific effects of removal surgery may have contributed to the observed outcomes. The lack of a head-to-head comparison in all available studies prohibits conclusive inferences about a causal relationship between implant removal and symptom control.

Elastic stable intramedullary nails (ESIN) ranked first among all implants to be considered for routine removal. This information may add to results from a recent survey of 273 pediatric and 99 non-pediatric specialists regarding implant removal in children [12]. While $64 \%$ and $50 \%$ of all respondents recommended removing DCPs after upper extremity fractures and interlocking nails after femoral shaft fractures, the different scenarios did not offer an ESIN option. Some authors admitted their inclination to remove flexible nails in children despite the lack of scientific evidence and the potential risk for refractures $[27,28]$.

Several limits of this investigation merit discussion. First, as a survey, it can only describe opinions and practice patterns, and does not allow for determining the actual effectiveness of implant removal. Questionnaire surveys are prone to multiple sources of bias (e.g., socially desired response bias) [29], and answers of the respondents may not reflect their true daily behaviour. In addition, recalled numbers may be incorrect. Recall bias may also have been introduced by remembering a recent successful or unsuccessful case. Second, European professionals represented the largest fraction of all respondents, thereby restricting the external validity of the findings. Third, the survey form may have missed certain scenarios, and some of the questions may also be regarded ambiguous or sketchy.

Table 4: Uncontrolled studies of the effectiveness of implant removal in symptomatic patients. Success includes complete or marked reduction of pain

\begin{tabular}{|c|c|c|c|c|c|c|c|}
\hline Author & Year & Implant & $\mathbf{n}$ & & Success & & Failure \\
\hline Richards [30] & 1992 & various & 46 & 42 & $91 \%(79-98 \%)$ & 4 & $9 \%(2-21 \%)$ \\
\hline Jacobsen [3I] & 1994 & ankle plates & 66 & 49 & $74 \%(62-84 \%)$ & 17 & $26 \%(16-38 \%)$ \\
\hline Court-Brown [32] & 1997 & intramedullary tibial nails & 62 & 60 & $97 \%(88-99 \%)$ & 2 & $3 \%(0-11 \%)$ \\
\hline Dodenhoff [33] & 1997 & intramedullary femoral nails & 17 & 11 & $65 \%(38-86 \%)$ & 6 & $35 \%(14-62 \%)$ \\
\hline Keating [34] & 1997 & intramedullary tibial nails & 49 & 39 & $80 \%(66-90 \%)$ & 10 & $20 \%(10-34 \%)$ \\
\hline Brown [7] & 2001 & ankle plates & 22 & 11 & $50 \%(28-72 \%)$ & 11 & $50 \%(28-72 \%)$ \\
\hline Gösling [6] & 2004 & intramedullary femoral nails & 58 & 45 & $78 \%(65-87 \%)$ & 13 & $22 \%(13-35 \%)$ \\
\hline Gösling [24] & 2005 & intramedullary tibial nails & 26 & 19 & $73 \%(52-88 \%)$ & 7 & $27 \%(12-48 \%)$ \\
\hline Weighted average & & & 346 & & $78 \%(69-88 \%)$ & & $22 \%(12-31 \%)$ \\
\hline
\end{tabular}

Failure includes no change and worsening of symptoms. Summary estimates were derived from random-effects meta-regression analysis 
We tried hard to cover a broad range of clinical settings, and to enrol a large and possibly representative sample of surgeons. Also, the response rate and the number of completed items make the estimates reliable. Apart from all design limitations, the findings may point towards a true public health problem. Since most surgeons are reluctant in charging patients for the procedure, reimbursement strategies need to be evaluated and adopted to the substantial time and effort associated with implant removal surgery.

\section{Conclusion}

There is a serious need to study the biological mechanisms and clinical determinants of symptomatic implants, and to develop clinical decision rules that may allow for identifying patients who will benefit most from implant removal. A controlled trial that compares removal to retention is strongly warranted.

\section{Competing interests}

The authors declare that they have no competing interests.

\section{Authors' contributions}

$\mathrm{BH}$ and DS had the idea for this study, developed the design, and designed the questionnaires. CvdW made substantial comments on both the study design and the questionnaires justifying authorship. DS performed all statistical analyses. BH and DS jointly drafted the manuscript. All authors read and approved the final version of this paper.

\section{Acknowledgements}

The authors thank Peter de Boer MD, Kai Bauwens MD, and Peter Heumann MD for reviewing the final version of the questionnaire. We thank Jannicke Juchli and Andreas Nebel for their outstanding technical support in organizing this survey. We acknowledge all the wonderful people at $A O$ Clinical Investigation and Documentation for their logistic contributions.

\section{References}

I. Bostman O, Pihlajamaki H: Routine implant removal after fracture surgery: a potentially reducible consumer of hospital resources in trauma units. I Trauma 1996, 41:846-849.

2. Beaupre GS, Csongradi J]: Refracture risk after plate removal in the forearm. J Orthop Trauma 1996, 10:87-92.

3. Davison BL: Refracture following plate removal in supracondylar-intercondylar femur fractures. Orthopedics 2003, 26:157-159.

4. Langkamer VG, Ackroyd CE: Removal of forearm plates. A review of the complications. J Bone Joint Surg $\mathrm{Br}$ 1990, 72:60I-604.

5. Sanderson PL, Ryan W, Turner PG: Complications of metalwork removal. Injury 1992, 23:29-30.

6. Gösling T, Hüfner T, Hankemeier S, Zelle BA, Müller-Heine A, Krettek $C$ : Femoral nail removal should be restricted in asymptomatic patients. Clin Orthop Relat Res 2004:222-226.

7. Brown OL, Dirschl DR, Obremskey WT: Incidence of hardwarerelated pain and its effect on functional outcomes after open reduction and internal fixation of ankle fractures. J Orthop Trauma 200I, I5:27I-274.

8. Kahle WK: The case against routine metal removal. J Pediatr Orthop 1994, 14:229-237.
9. Krischak GD, Gebhard F, Mohr W, Krivan V, Ignatius A, Beck A, Wachter NJ, Reuter P, Arand M, Kinzl L, Claes LE: Difference in metallic wear distribution released from commercially pure titanium compared with stainless steel plates. Arch Orthop Trauma Surg 2004, I 24: 104-I I3

10. Serhan H, Slivka M, Albert T, Kwak SD: Is galvanic corrosion between titanium alloy and stainless steel spinal implants a clinical concern? Spine J 2004, 4:379-387.

II. Kasai Y, lida R, Uchida A: Metal concentrations in the serum and hair of patients with titanium alloy spinal implants. Spine 2003, 28:1320-1326.

12. Loder RT, Feinberg JR: Orthopaedic implants in children: survey results regarding routine removal by the pediatric and nonpediatric specialists. J Pediatr Orthop 2006, 26:510-519.

13. Mølster A, Behring J, Gjerdet NR, Ekeland A: Fjerning av osteosyntesemateriale. Tidsskr Nor Laegeforen 2002, 122:2274-2276.

14. Bhandari M, Guyatt GH, Swiontkowski MF, Tornetta P III, Hanson B, Weaver B, Sprague S, Schemitsch EH: Surgeons' preferences for the operative treatment of fractures of the tibial shaft. An international survey. J Bone Joint Surg Am 200I, 83-A: 1746-1752.

15. Bhandari M, Guyatt GH, Tornetta P III, Swiontkowski MF, Hanson B, Sprague S, Syed A, Schemitsch EH: Current practice in the intramedullary nailing of tibial shaft fractures: an international survey. J Trauma 2002, 53:725-732.

16. Bhandari M, Devereaux PJ, Tornetta P III, Swiontkowski MF, Berry DJ, Haidukewych G, Schemitsch EH, Hanson BP, Koval K, Dirschl D, Leece P, Keel M, Petrisor B, Heetveld M, Guyatt GH: Operative management of displaced femoral neck fractures in elderly patients. An international survey. J Bone Joint Surg Am 2005, 87:2I22-2I30.

17. Goodman SN, Berlin JA: The use of predicted confidence intervals when planning experiments and the misuse of power when interpreting results. Ann Intern Med 1994, I $21: 200-206$.

18. Moore RM Jr., Hamburger S, Jeng LL, Hamilton PM: Orthopedic implant devices: prevalence and sociodemographic findings from the 1988 National Health Interview Survey. J Appl Biomater |99|, 2:|27-|3|.

19. Cook SD, Renz EA, Barrack RL, Thomas KA, Harding AF, Haddad RJ Jr., Milicic M: Clinical and metallurgical analysis of retrieved internal fixation devices. Clin Orthop Relat Res 1985:236-247.

20. Evans NA, Evans RO: Playing with metal: fracture implants and contact sport. Br J Sports Med 1997, 3 I:319-32I.

21. Peterson HA: Metallic implant removal in children. J Pediatr Orthop 2005, 25:107-II5.

22. Townend M, Parker P: Metalwork removal in potential army recruits. Evidence-based changes to entry criteria. J R Army Med Corps 2005, I 51:2-4.

23. Brown RM, Wheelwright EF, Chalmers J: Removal of metal implants after fracture surgery--indications and complications. J R Coll Surg Edinb 1993, 38:96-100.

24. Gösling T, Hüfner T, Hankemeier S, Müller U, Richter M, Krettek C: Indikation zur Entfernung von Tibiamarknägeln. Chirurg 2005, 76:789-794.

25. Minkowitz RB, Bhadsavle S, Walsh M, Egol KA: Removal of painful orthopaedic implants after fracture union. J Bone Joint Surg Am 2007, 89:1906-1912.

26. Evers B, Habelt R, Gerngross H: Indication, timing and complications of plate removal after forearm fractures: results of a metaanalysis including 635 cases. J Bone Joint Surg Br 2004, 86:289.

27. Simanovsky N, Tair MA, Simanovsky N, Porat S: Removal of flexible titanium nails in children. J Pediatr Orthop 2006, 26: I88- 192.

28. Vierhout BP, Sleeboom C, Aronson DC, Van Walsum AD, Zijp G, Heij HA: Long-term outcome of elastic stable intramedullary fixation (ESIF) of femoral fractures in children. Eur J Pediatr Surg 2006, 16:432-437.

29. Trelle S: Accuracy of responses from postal surveys about continuing medical education and information behavior: experiences from a survey among German diabetologists. BMC Health Serv Res 2002, 2:I5.

30. Richards RH, Palmer JD, Clarke NM: Observations on removal of metal implants. Injury 1992, 23:25-28.

31. Jacobsen S, Honnens L, Jensen CM, Torholm C: Removal of internal fixation--the effect on patients' complaints: a study of 66 cases of removal of internal fixation after malleolar fractures. Foot Ankle Int 1994, I5: I70-I7I. 
32. $\mathrm{CM} C B$, Gustilo $T$, Shaw $A D$ : Knee pain after intramedullary tibial nailing: its incidence, etiology, and outcome. J Orthop Trauma 1997, I I:103-105.

33. Dodenhoff RM, Dainton JN, Hutchins PM: Proximal thigh pain after femoral nailing. Causes and treatment. J Bone Joint Surg $\mathrm{Br}$ 1997, 79:738-74I.

34. Keating JF, Orfaly R, O'Brien PJ: Knee pain after tibial nailing. J Orthop Trauma 1997, I I:10-13.

\section{Pre-publication history}

The pre-publication history for this paper can be accessed here:

http://www.biomedcentral.com/1471-2474/9/73/prepub

Publish with Bio Med Central and every scientist can read your work free of charge

"BioMed Central will be the most significant development for disseminating the results of biomedical research in our lifetime. "

Sir Paul Nurse, Cancer Research UK

Your research papers will be:

- available free of charge to the entire biomedical community

- peer reviewed and published immediately upon acceptance

- cited in PubMed and archived on PubMed Central

- yours - you keep the copyright

Submit your manuscript here:

http://www.biomedcentral.com/info/publishing_adv.asp 